\title{
Mechanical Properties of Low Densities Lightweight Foamed Concrete Strengthen with Raw Empty Fruit Bunch Fibre
}

\author{
Md Azree OTHUMAN MYDIN*, Mohd Nasrun MOHD NAWI, Anas A. SALAMEH
}

\begin{abstract}
Lightweight foamed concrete (LFC) is well known as a low-density concrete with a wide range of applications. LFC is good under compression but very poor in bending and tensile stresses, as it produces multiple microcracks and cannot withstand the additional stress induced by applied forces without supplementary reinforcing components especially in low densities LFC. Hence this study experimentally examined the effectiveness of the inclusion of oil palm empty fruit bunch (EFB) fibre in low densities lightweight foamed concrete (LFC) to enhance its mechanical properties. LFC specimens were reinforced with EFB fibre at volume fractions of $0.15 \%, 0.30 \%$, $0.45 \%$, and $0.60 \%$. Three low densities LFC had been considered in this study namely $550 \mathrm{~kg} / \mathrm{m}^{3}, 750 \mathrm{~kg} / \mathrm{m}^{3}$ and $950 \mathrm{~kg} / \mathrm{m}^{3}$ with a constant cement-to-sand ratio of $1: 1.5$, and cement-to-water ratio of 0.4 . The parameters assessed were compressive strength, bending strength and splitting tensile strength. The results revealed that the inclusion of $0.45 \%$ of EFB fibre in LFC helps to give the best results for the compressive, bending and splitting tensile strengths. EFB fibre acts as fillers bridging the gaps and microcracks within the LFC, resulting in the high strengths. The EFB fibre helped to avoid the promulgation of cracks in the plastic state in the cement matrix when the load was applied. Though, beyond the optimum level of EFB fibre addition, agglomeration, and the non-uniform dispersion of fibres was observed, which results in the lowered performance of the low densities LFC.
\end{abstract}

Keywords: bending; compressive strength; empty fruit bunch fibre; foamed concrete; splitting tensile

\section{INTRODUCTION}

Recently, lightweight foamed concrete (LFC) has gained major attention among the industrial players and building material manufacturers owing to its excellent thermal and mechanical properties such as high flowability, low self-weight, good thermal performance and sound insulation properties [1-3]. Besides, LFC is an environmentally friendly building material because of its minimal usage of aggregate and high potential to integrate waste material such as natural fibres [4]. LFC is a mixture of cement paste (slurry) and homogeneous foam introduced using a suitable foaming agent, which can be regarded as self-compacting materials [5]. LFC has an air content of more than $25 \%$ by volume, thus distinguishing itself from highly air entrained materials [6].

In practice, it delivers pleasing solutions to address numerous encounters faced in the construction activities. The low self-weight of LFC makes it capable for load reduction in tunnel construction [7] and it could reduce the size of foundation in structure design of building [8]. Though increasing consideration has been given to LFC worldwide, its application in Malaysian construction industry is still in its infancy. Nevertheless, it has been utilized in a number of applications such as in the smart tunnel project Kuala Lumpur, Malaysia [9]. The cost of LFC is majorly dependent on the cement content and the foam dose used in the mixture [10]. Therefore, the development of LFC is envisaged to be a contribution towards green construction and sustainability [11]. One of the drawbacks of LFC is weakness in tension although it has reasonable compressive strength to be used as semistructural components in building construction [12]. Despite that, LFC is not only being applied primarily for level correction in housing development and as fill-in material for load works, but is also being used as a semistructural element in construction [13].

Hence this research attempts to study the potential use of empty fruit bunch fibre produced by oil palm industry in LFC to improve its mechanical properties. The addition of natural fibres into LFC is to improve the bonding between cementitious composite [14]. It should be pointed out that addition of small volumetric fractions of short natural fibres can reduce the impact of early-age reduction of the concrete's durability and mechanical properties $[15,16]$. It also can restrict the growth of cracks under loads. Natural fibre-reinforced LFC has many benefits, such as being light in weight, inexpensive, durable, and of good rigidity [17, $18]$.

\subsection{MATERIALS, MIX DESIGN AND EXPERIMENTAL SETUP 2.1 Materials}

Ordinary Portland Cement was the cement used, in accordance with BS EN 12 [19] standard, which was supplied by YTL Castle Cement Marketing Sdn Bhd. All the cement used was in good condition and stored in a covered area. The fine sand utilized for this investigation was natural fine sand attained from the local supplier. This fine sand had a maximum width of $2 \mathrm{~mm}$ and a 600 micron sieve, and a passage of $60 \%$ to $90 \%$. The suitability of the sand had to follow BS EN 822 [20]. Next, the foaming agent used was a protein-based foaming agent, specifically Noraite PA-1. The foam was produced by a portable foaming generator machine, namely the Portafoam TM-1 machine. The water-cement ratio used for this research was 0.45 , because this ratio can achieve reasonable workability. The fibre used was raw empty fruit bunch fibre, which was freshly collected from an industrial unit after processing. The EFB fibre was placed under the sun to dry (Fig. 1).

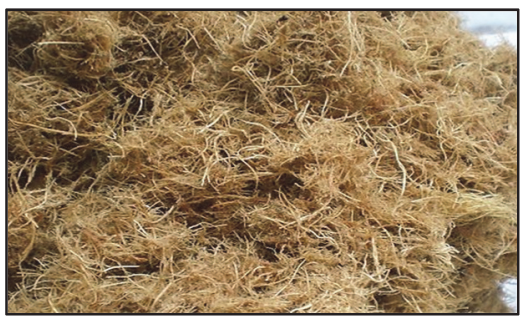

Figure 1 Dried EFB fibre 
Fig. 2 shows the surface morphology details of EFB fibre. Tab. 1 and Tab. 2 visualize the chemical composition and mechanical properties of EFB fibre respectively.

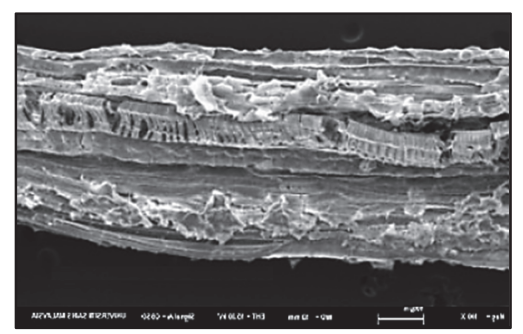

Figure 2 Surface morphology of EFB fibre

Table 1 Chemical composition of EFB fibre

\begin{tabular}{|l|c|}
\hline Lignin / \% & $29.8 \pm 3.3$ \\
\hline Cellulose / \% & $28.1 \pm 0.5$ \\
\hline Hemicellulose / \% & $33.5 \pm 4.1$ \\
\hline Extractives / \% & $2.8 \pm 0.3$ \\
\hline
\end{tabular}

Table 2 Mechanical properties of EFB fibre

\begin{tabular}{|l|c|}
\hline Density $/ \mathrm{g} / \mathrm{cm}^{3}$ & 0.96 \\
\hline Length / mm & 20 \\
\hline Diameter of fibre / $\mu \mathrm{m}$ & 12.81 \\
\hline Diameter of lumen / $\mu \mathrm{m}$ & 6.94 \\
\hline Tensile strength / MPa & 125 \\
\hline Young's modulus / GPa & 11.7 \\
\hline Elongation at break / \% & 11.94 \\
\hline
\end{tabular}

\subsection{Mix Design}

A total of $15 \mathrm{LFC}$ mixes and 3 densities, $550 \mathrm{~kg} / \mathrm{m}^{3}$, $750 \mathrm{~kg} / \mathrm{m}^{3}$ and $950 \mathrm{~kg} / \mathrm{m}^{3}$, were prepared. The volume fractions of EFB fibre used were $0.15 \%, 0.30 \%, 0.45 \%$ and $0.60 \%$. For all the mixes, the sand-cement ratio used was $1: 1.5$ and the water-cement ratio used was kept constant at 0.4. Tab. 3 shows the mix design of LFC in this study.

\begin{tabular}{|c|c|c|c|c|c|}
\multicolumn{7}{c}{ Table 3 LFC mix design } \\
\begin{tabular}{|c|c|c|c|c|} 
Density \\
$/ \mathrm{kg} / \mathrm{m}^{3}$
\end{tabular} & $\begin{array}{c}\text { EFB fibre } \\
/ \%\end{array}$ & $\begin{array}{c}\text { Cement / } \\
\mathrm{kg}\end{array}$ & $\begin{array}{c}\text { Sand / } \\
\mathrm{kg}\end{array}$ & Water / kg & $\begin{array}{c}\text { Mix Ratio / } \\
\text { c:s:w }\end{array}$ \\
\hline 550 & - & 21.58 & 32.38 & 8.63 & $1: 1.5: 0.4$ \\
\hline 550 & 0.15 & 21.58 & 32.38 & 8.63 & $1: 1.5: 0.4$ \\
\hline 550 & 0.30 & 21.58 & 32.38 & 8.63 & $1: 1.5: 0.4$ \\
\hline 550 & 0.45 & 21.58 & 32.38 & 8.63 & $1: 1.5: 0.4$ \\
\hline 550 & 0.60 & 21.58 & 32.38 & 8.63 & $1: 1.5: 0.4$ \\
\hline 750 & - & 28.93 & 43.40 & 11.57 & $1: 1.5: 0.4$ \\
\hline 750 & 0.15 & 28.93 & 43.40 & 11.57 & $1: 1.5: 0.4$ \\
\hline 750 & 0.30 & 28.93 & 43.40 & 11.57 & $1: 1.5: 0.4$ \\
\hline 750 & 0.45 & 28.93 & 43.40 & 11.57 & $1: 1.5: 0.4$ \\
\hline 750 & 0.60 & 28.93 & 43.40 & 11.57 & $1: 1.5: 0.4$ \\
\hline 950 & - & 36.28 & 54.42 & 14.51 & $1: 1.5: 0.4$ \\
\hline 950 & 0.15 & 36.28 & 54.42 & 14.51 & $1: 1.5: 0.4$ \\
\hline 950 & 0.30 & 36.28 & 54.42 & 14.51 & $1: 1.5: 0.4$ \\
\hline 950 & 0.45 & 36.28 & 54.42 & 14.51 & $1: 1.5: 0.4$ \\
\hline 950 & 0.60 & 36.28 & 54.42 & 14.51 & $1: 1.5: 0.4$ \\
\hline
\end{tabular}

\subsection{Experimental Setup}

Tests were carried out investigating the mechanical properties with the inclusion of EFB fibre which includes compression test, bending test and splitting tensile test. The specimen size for compression test is $100 \mathrm{~mm} \times 100 \mathrm{~mm} \times$ $100 \mathrm{~mm}$ cube which was performed according to BS EN 12390-3 standard [21]. For bending test, prism of $100 \mathrm{~mm}$ $\times 100 \mathrm{~mm} \times 500 \mathrm{~mm}$ was used and finally for splitting tensile strength according to ASTM C 348 standard [22], cylinder of $100 \mathrm{~mm}$ diameter $\times 200 \mathrm{~mm}$ height was considered according to ASTM C496/C 496M standard [23]. Fig. 5, Fig. 6 and Fig. 7 show the arrangement of compression, bending and splitting tensile tests respectively.

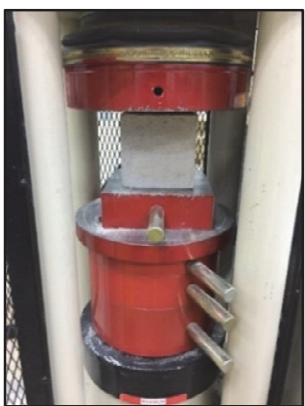

Figure 3 Compression test arrangement

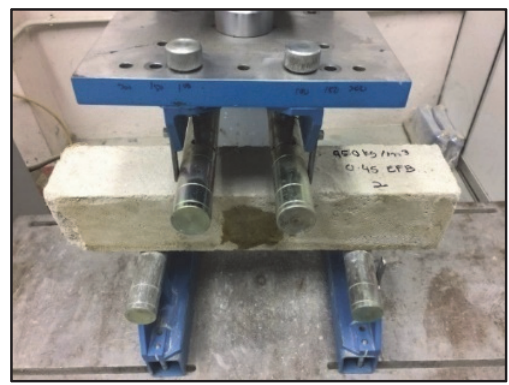

Figure 4 Bending test arrangement

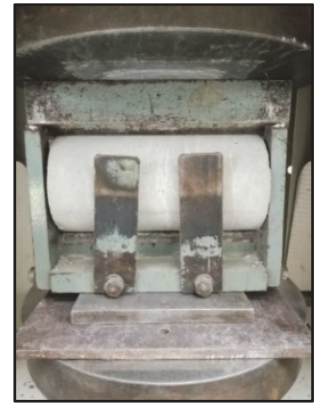

Figure 5 Splitting tensile test arrangement

\subsection{RESULTS AND DISCUSSION \\ 3.1 Compressive Strength}

The results of the compression strength tests carried out are shown in Fig. 6 to Fig. 8 for all three densities considered in this study. In general, we can clearly see from these figures that adding EFB into LFC had improved the compressive strength no matter what is the volume fraction. Testing at 7, 28, and 56 days of curing consistently showed that overall, the mixes resulted in better compressive strength compared to the control specimen for all densities. The optimum volume fraction of EFB fibre was $0.45 \%$. The highest compressive strength achieved at day 56 was $1.72 \mathrm{~N} / \mathrm{mm}^{2}, 2.78 \mathrm{~N} / \mathrm{mm}^{2}$ and 3.99 $\mathrm{N} / \mathrm{mm}^{2}$ with the inclusion of $0.45 \%$ volume fraction of EFB fibre for $550 \mathrm{~kg} / \mathrm{m}^{3}, 750 \mathrm{~kg} / \mathrm{m}^{3}$ and $950 \mathrm{~kg} / \mathrm{m}^{3}$ densities respectively compared to control specimen (with no fibre addition) which only attained compressive strength of $1.19 \mathrm{~N} / \mathrm{mm}^{2}\left(550 \mathrm{~kg} / \mathrm{m}^{3}\right), 2.23 \mathrm{~N} / \mathrm{mm}^{2}(750$ $\left.\mathrm{kg} / \mathrm{m}^{3}\right)$ and $3.17 \mathrm{~N} / \mathrm{mm}^{2}\left(950 \mathrm{~kg} / \mathrm{m}^{3}\right)$. Beyond the optimum level of EFB fibre addition, agglomeration, and the nonuniform dispersion of fibres was observed, which results in the drop of compressive strength (at $0.6 \%$ volume fraction 
of EFB fibre). At $0.45 \%$ volume fraction of EFB fibre, the fibres and the cement matrix attained high compaction, which resulted in good mix homogeneity. Compressive strength and bulk density are slightly enhanced with low fibre content ranging between $0.20 \%$ to $0.45 \%$ [24]. High addition of natural fibre into the LFC mixture, especially the low densities, will retard the hydration process, thus resulting in low strength of LFC although it will gain strength after a certain age [25]. As LFC is comprised of void gaps of a wide range of sizes and shapes in the cementitious matrix and micro-cracks at the transition zone between the matrix, the addition of EFB fibre will assist in the failure of the mode under compression stress [26].

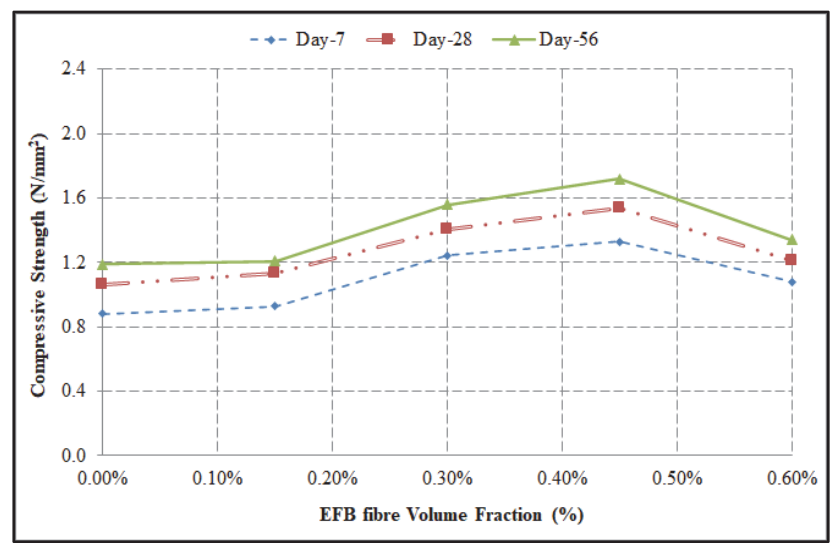

Figure 6 Compressive strength of $550 \mathrm{~kg} / \mathrm{m}^{3}$ density LFC of different percentages of EFB fibre

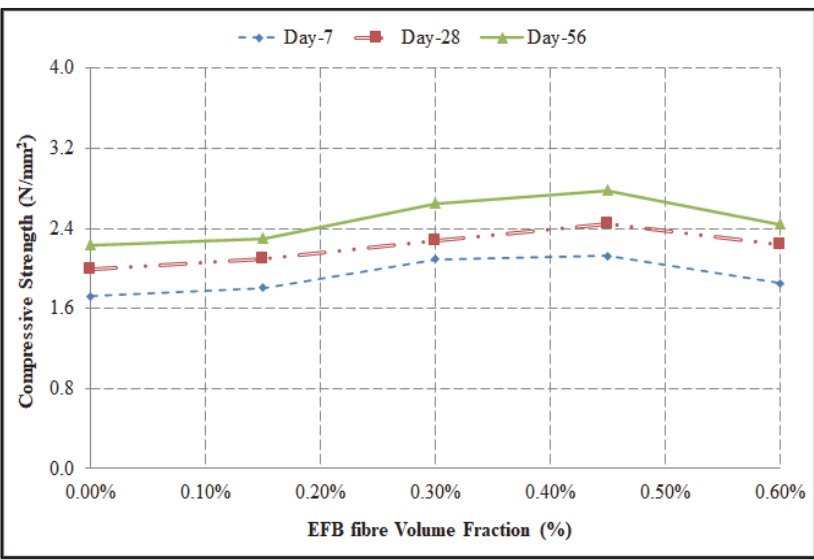

Figure 7 Compressive strength of $750 \mathrm{~kg} / \mathrm{m}^{3}$ density LFC of different percentages of EFB fibre

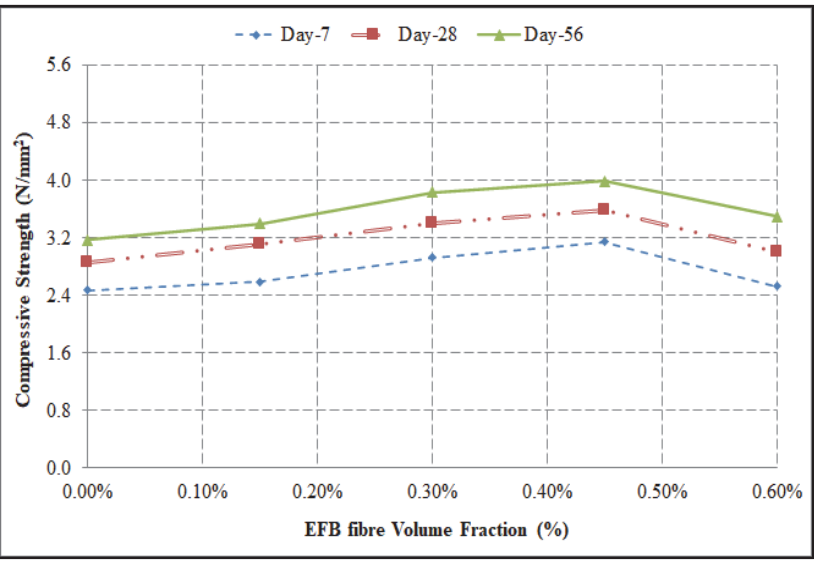

Figure 8 Compressive strength of $950 \mathrm{~kg} / \mathrm{m}^{3}$ density LFC of different percentages of EFB fibre

\subsection{Bending Strength}

In general, the bending strength of LFC with the inclusion of EFB fibre increased dramatically for all densities in spite of the volume fraction of fibre added into LFC mix. Fig. 9 to Fig. 11 visualize the results of bending strength attained for $550 \mathrm{~kg} / \mathrm{m}^{3}, 750 \mathrm{~kg} / \mathrm{m}^{3}$ and $950 \mathrm{~kg} / \mathrm{m}^{3}$ densities correspondingly. The control mix (LFC with no fibre addition) obtained the lowest bending strength showing only a slight increment along with the testing age. However, LFC specimens with the addition of EFB fibre show a significant increment in bending strength by age. At day 28, the bending strength of control LFC was 0.27 $\mathrm{N} / \mathrm{mm}^{2}, 0.51 \mathrm{~N} / \mathrm{mm}^{2}$ and $0.73 \mathrm{~N} / \mathrm{mm}^{2}$ for $550 \mathrm{~kg} / \mathrm{m}^{3}, 750$ $\mathrm{kg} / \mathrm{m}^{3}$ and $950 \mathrm{~kg} / \mathrm{m}^{3}$ densities respectively. The same as compressive strength, the optimum volume fraction of EFB fibre that gave the best results of bending strength was $0.45 \%$. The uppermost bending strengths accomplished at day 56 were $0.49 \mathrm{~N} / \mathrm{mm}^{2}, 0.77 \mathrm{~N} / \mathrm{mm}^{2}$ and $1.17 \mathrm{~N} / \mathrm{mm}^{2}$ with the presence of $0.45 \%$ volume fraction of EFB fibre for $550 \mathrm{~kg} / \mathrm{m}^{3}, 750 \mathrm{~kg} / \mathrm{m}^{3}$ and $950 \mathrm{~kg} / \mathrm{m}^{3}$ densities correspondingly. The addition of EFB fibre in LFC plays an important role in strengthening LFC cementitious matrix and it changed the material characteristic from brittle to ductile elastic-plastic. EFB fibre contributes to enhancing the bending strength of LFC for all densities. However, undue EFB fibre volume fraction added into LFC (more than $0.45 \%$ ) may lead to reducing the bonding between the cement matrix and the fibre [27].

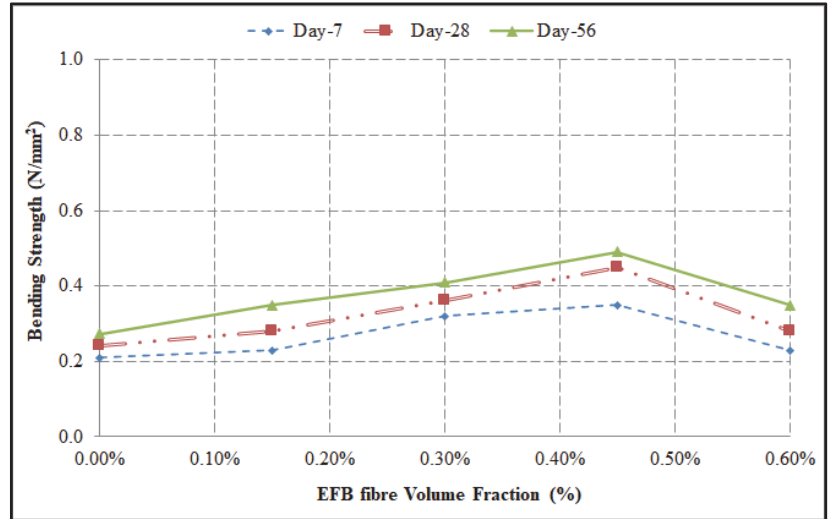

Figure 9 Bending strength of $550 \mathrm{~kg} / \mathrm{m}^{3}$ density LFC of different percentages of EFB fibre

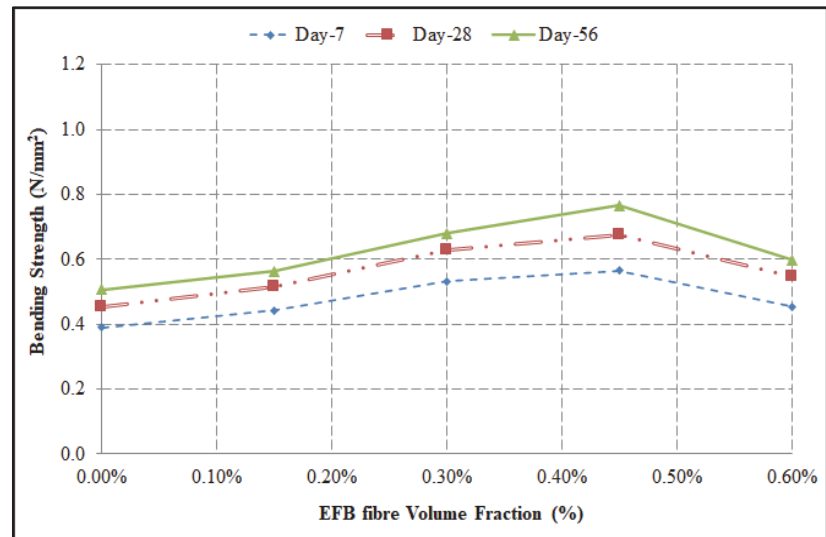

Figure 10 Bending strength of $750 \mathrm{~kg} / \mathrm{m}^{3}$ density LFC of different percentages of EFB fibre 
Utilization of a $0.45 \%$ volume fraction of EFB fibre can be considered an optimal percentage for this type of concrete based on the increment of results obtained. The increase of bending strength is well-suited with the compressive strength intensification. High bending strength attained is due to the reduction of porosity in LFC mixes $[28,29]$. Thus, based on the result of the bending strength gotten, it can be resolved that the addition of EFB fibre into LFC can enhance bending strength by age.

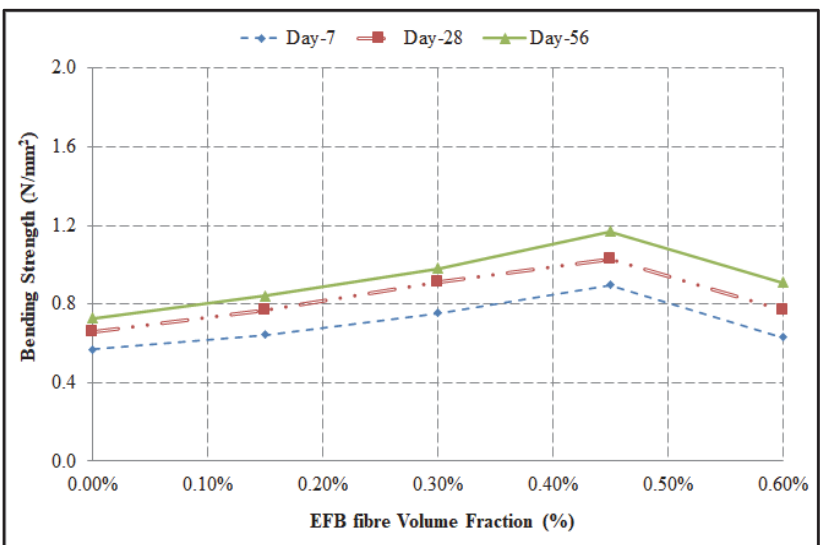

Figure 11 Bending strength of $950 \mathrm{~kg} / \mathrm{m}^{3}$ density LFC of different percentages of EFB fibre

\subsection{Splitting Tensile Strength}

Fig. 12 to Fig. 14 show the results of splitting tensile strength of all the three densities considered in this research with the addition of different volume fractions of EFB fibre. Same trend was found in which $0.45 \%$ volume fraction of EFB fibre inclusion led to the best results of splitting tensile strength. As can be seen from Fig. 12 to Fig. 14, the highest splitting tensile strength achieved at day 56 was $0.35 \mathrm{~N} / \mathrm{mm}^{2}, 0.55 \mathrm{~N} / \mathrm{mm}^{2}$ and $0.83 \mathrm{~N} / \mathrm{mm}^{2}$ with the inclusion of $0.45 \%$ volume fraction of EFB fibre for $550 \mathrm{~kg} / \mathrm{m}^{3}, 750 \mathrm{~kg} / \mathrm{m}^{3}$ and $950 \mathrm{~kg} / \mathrm{m}^{3}$ densities respectively compared to control specimen (with no fibre addition) which only attained compressive strength of $0.20 \mathrm{~N} / \mathrm{mm}^{2}$ $\left(550 \mathrm{~kg} / \mathrm{m}^{3}\right), 0.31 \mathrm{~N} / \mathrm{mm}^{2}\left(750 \mathrm{~kg} / \mathrm{m}^{3}\right)$ and $0.47 \mathrm{~N} / \mathrm{mm}^{2}$ $\left(950 \mathrm{~kg} / \mathrm{m}^{3}\right)$.

Beyond the optimum level of EFB fibre addition, agglomeration, and the non-uniform dispersion of fibres was observed, which resulted in the drop of compressive strength (at $0.6 \%$ volume fraction of EFB fibre). The enhancement of splitting tensile strength is due to the increase in toughness of LFC due to the presence of EFB fibres where $0.45 \%$ of fibre content addition enhances the increment of tensile strength in LFC by promoting optimum pozzolanic reaction with OPC content, thus producing denser and stronger concrete.

The data obtained in this study indicates that the addition of EFB fibres enhances the splitting tensile strength of LFC regardless of any volume fraction of EFB fibre. The elongation at break of single EFB fibre is considered low, resulting in excellent tensile strength when added into concrete $[30,31]$. Elongation at break expresses the ability of the fibre to resist to changes of shape without formation of crack in cementitious composite.

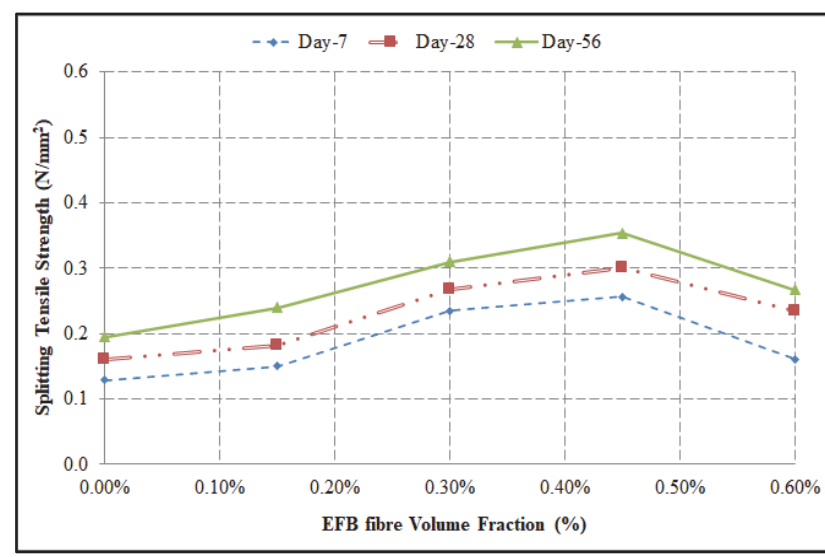

Figure 12 Tensile strength of $550 \mathrm{~kg} / \mathrm{m}^{3}$ density LFC of different percentages of EFB fibre

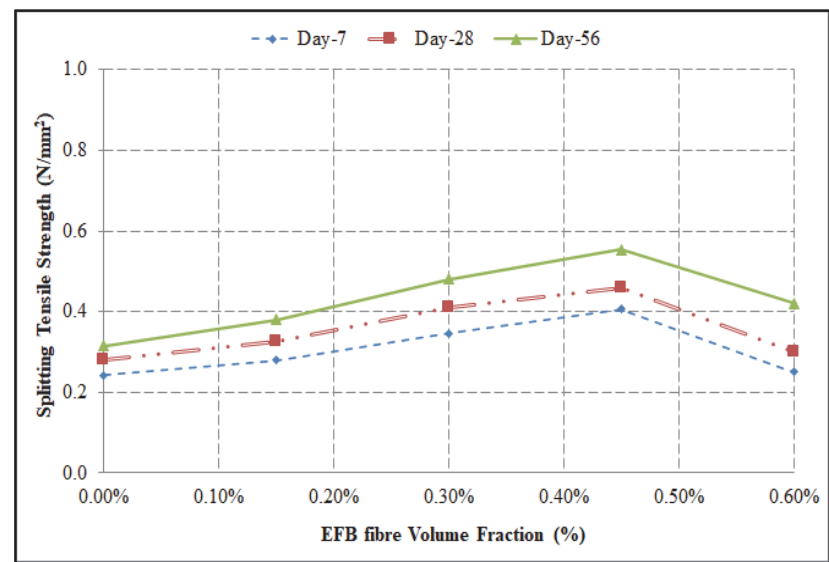

Figure 13 Tensile strength of $750 \mathrm{~kg} / \mathrm{m}^{3}$ density LFC of different percentages of EFB fibre

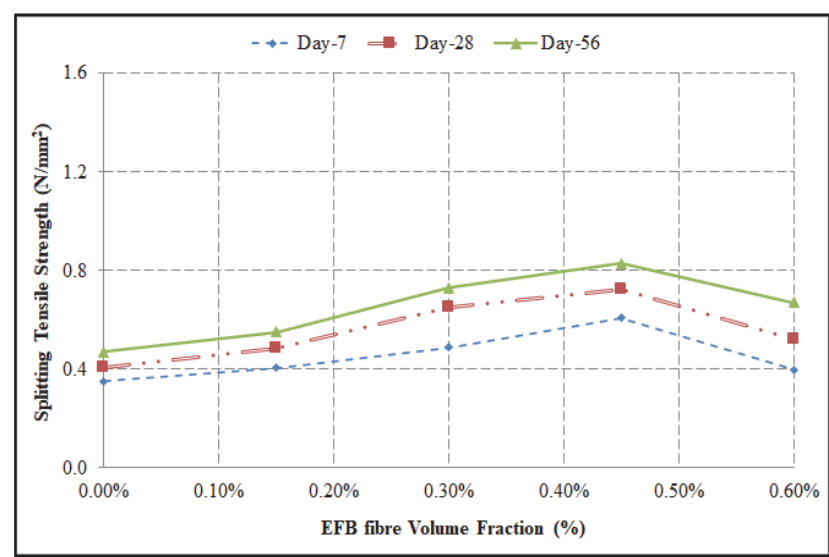

Figure 14 Tensile strength of $950 \mathrm{~kg} / \mathrm{m}^{3}$ density LFC of different percentages of EFB fibre

\subsection{Scanning Electron Microscope Analysis}

Scanning Electron Microscope analysis was carried out on failed specimens under compression, bending and tensile loads in order to obtained a better understanding on how the specimens failed. Fig. 15 displays the SEM micrograph result of fractured surface of LFC reinforced with EFB fibre under compression.

Even though inclusion of EFB fibre plays an important role to improve the interfacial bonding between the LFC cement paste and the EFB fibre, the indication of pull-out of EFB fibre can be observed under compressive load especially for lower density LFC $\left(550 \mathrm{~kg} / \mathrm{m}^{3}\right)$. The lower density LFC which contains large pore sizes was incapable 
to endure extra load under compressive load due to poor adhesion. Nevertheless, the addition of EFB fibre aided in bounding the LFC cementitious matrix in the lateral direction, hence enhanced the detention effect and circuitously upsurged the compressive strength of LFC when the specimens were under compression.

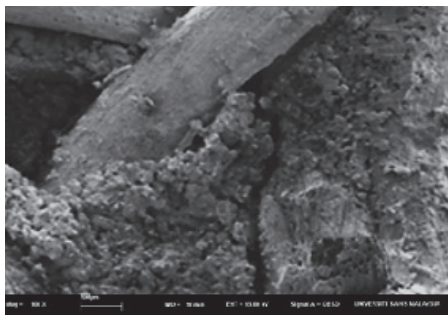

(a) $550 \mathrm{~kg} / \mathrm{m}^{3}$ density

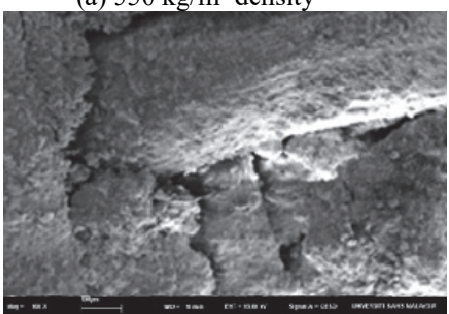

(b) $950 \mathrm{~kg} / \mathrm{m}^{3}$ density

Figure 15 SEM micrograph images of fractured LFC specimen under compression. There was an evidence of EFB fibre pull-out can be observed from these two SEM images

Next, Fig. 16 shows the SEM micrograph result of ruptured surface of LFC reinforced with EFB fibre under bending load. As far as bending load is concerned, there was very little sign of EFB fibre pull-out denoting that the additional stress which was transferred to the EFB fibres in the hardenned cement matrix composite was extremly strong resulting in EFB fibre rupture rather than fibre pullout as per that occuring under compressive load.

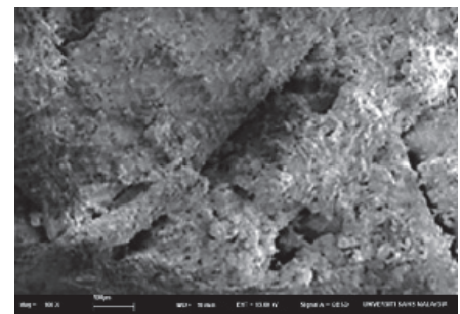

(a) $550 \mathrm{~kg} / \mathrm{m}^{3}$ density

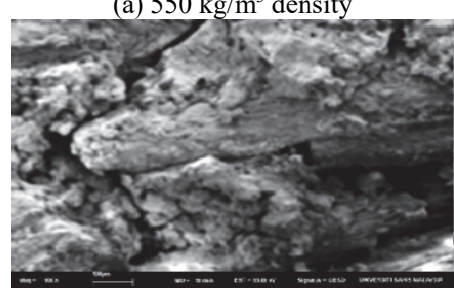

(b) $950 \mathrm{~kg} / \mathrm{m}^{3}$ density

Figure 16 SEM micrograph images of failed LFC specimen under bending load. Ruptured EFB fibres were more dominant rather than fibre pull-out

Fig. 17 discloses the SEM microscopy result of fractured surface of LFC strengthened with EFB fibre under tensile load. The result revealed that EFB fibre pullout was not dominant compared to breakage of fibre. There was also excellent interphase bonding between the EFB fibre and the LFC cement matrix. As a summary, it can be concluded that the addition of EFB fibre in LFC assists in bounding the cementitious composite in the transversal direction, and consequently improves the restraint effect when the concrete is hardenned and at the same time increases the tensile strength of LFC.

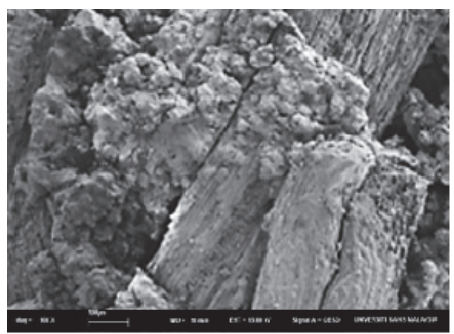

(a) $550 \mathrm{~kg} / \mathrm{m}^{3}$ density

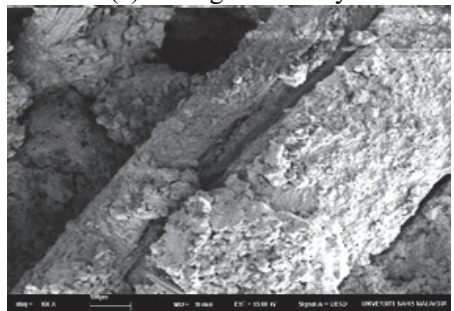

(b) $950 \mathrm{~kg} / \mathrm{m}^{3}$ density

Figure 17 SEM micrograph images of ruptured LFC specimen under tension. EFB fibre breakage voluminously occurred with minimal indication of fibre pullout under tensile load

\section{CONCLUSION}

This research experimentally investigated the effectiveness of the inclusion of oil palm empty fruit bunch (EFB) fibre in low densities lightweight foamed concrete (LFC) to enhance its mechanical properties. The volume fractions of EFB added in LFC mixes were $0.15 \%, 0.30 \%$, $0.45 \%$, and $0.60 \%$. Three low densities LFC had been cast and tested namely $550 \mathrm{~kg} / \mathrm{m}^{3}, 750 \mathrm{~kg} / \mathrm{m}^{3}$ and $950 \mathrm{~kg} / \mathrm{m}^{3}$. The parameters assessed were compressive strength, bending strength and splitting tensile strength. The summary of the findings from this study are outlined below:

i.Integration of $0.45 \%$ of EFB fibre in LFC aids to give the best results for the compressive, bending and splitting tensile strengths.

ii.EFB fibre acts as fillers and they bridge the gaps and micro-cracks within the LFC, resulting in the high strengths especially under bending and tensile loads.

iii.EFB fibre helped to evade the promulgation of cracks in the plastic state in the cement matrix when the load was applied.

iv.Nevertheless, beyond the optimum volume fraction of EFB fibre addition $(0.45 \%)$, agglomeration, and the nonuniform dispersion of fibres was observed, which results in the lowered strengths of the low densities LFC.

\section{REFERENCES}

[1] Jones, M. R. \& Mccarthy, A. (2005). Preliminary views on the potential of foamed concrete as a structural material. Magazine of Concrete Research, 57(1), 21-31. https://doi.org/10.1680/macr.2005.57.1.21

[2] Sang, G., Zhu, Y., Yang, G., \& Zhang, H. (2015). Preparation and characterization of high porosity cementbased foam material. Construction and Building Materials, 91, 133-137. https://doi.org/10.1016/j.conbuildmat.2015.05.032

[3] Serri, E., Suleiman, M. Z., \& Mydin M. A. O. (2014). The effects of oil palm shell aggregate shape on the thermal 
properties and density of concrete. Advanced Materials Research, 935, 172-175.

https://doi.org/10.4028/www.scientific.net/AMR.935.172

[4] Panesar, D. (2013). Cellular concrete properties and the effect of synthetic and protein foaming agents. Construction and Building Materials, 44, 575-584. https://doi.org/10.1016/j.conbuildmat.2013.03.024

[5] Harith, I. K. (2018). Study on polyurethane foamed concrete for use in structural applications. Case studies in construction materials, 8, 79-86. https://doi.org/10.1016/j.cscm.2017.11.005

[6] Oren, O. H., Gholampour, A., Gencel, O., Ozbakkaloglu, T. (2020). Physical and mechanical properties of foam concretes containing granulated blast furnace slag as fine aggregate. Construction and Building Materials, 238, 117774. https://doi.org/10.1016/j.conbuildmat.2019.117774

[7] Prakash, R., Thenmozhi, R., Raman, S. N., \& Subramanian, C. (2019). Characterization of eco-friendly steel fiberreinforced concrete containing waste coconut shell as coarse aggregates and fly ash as partial cement replacement. Structural Concrete. https://doi.org/10.1002/suco.201800355

[8] Ozlutas, K. (2015). Behaviour of Ultra-low Density Foamed Concrete. Doctoral dissertation, University of Dundee.

[9] Lim, S. K., Tan, C. S., Lim, O. Y., \& Lee, Y. L. (2013). Fresh and hardened properties of lightweight foamed concrete with palm oil fuel ash as filler. Construction and Building Materials, 46, 39-47. https://doi.org/10.1016/j.conbuildmat.2013.04.015

[10] Suhaili, S. S., Mydin, M. A. O. (2020). Potential of stalk and spikelets of empty fruit bunch fibres on mechanical properties of lightweight foamed concrete. International Journal of Scientific and Technology Research., 9(3), 31993204.

[11] Thakrele, M. H. (2014). Experimental study on foam concrete. International Journal of Civil, Structural, Environmental and Infrastructure Engineering Research and Development, 4(1), 145-158

[12] Sumit, C., Sarada, P. K., Aparna, R, Ratan, K. B., Basudam, A., \& Majumder, S. B. (2013). Improvement of the mechanical properties of jute fiber reinforced cement mortar: A statistical approach. Construction and Building Materials, 38, 776-784. https://doi.org/10.1016/j.conbuildmat.2012.09.067

[13] Ramamurthy, K., Kunhanandan Nambiar, E. K., \& Indu Siva Ranjani, G. (2009). A classification of studies on properties of foam concrete. Cement and Concrete Composites, 31(6), 388-396. https://doi.org/10.1016/j.cemconcomp.2009.04.006

[14] Munir, A., Abdullah, H., Sofyan, I., \& Safwan. (2015). Utilization of palm oil fuel ash (POFA) in producing lightweight foamed concrete for non-structural building material. Procedia Engineering, 125, 739-746. https://doi.org/10.1016/j.proeng.2015.11.119

[15] Moon, A. S., Varghese, V., \& Waghmare, S. S. (2015). Foam Concrete as A Green Building Material. International Journal for Research in Emerging Science and Technology, 2(9), 25-32.

[16] Mydin, M. A. O., Musa, M., \& Ghani, A. N. A. (2016). Fiber glass strip laminates strengthened lightweight foamed concrete: Performance index, failure modes and microscopy analysis. AIP Conference Proceedings, 2018, 020111. https://doi.org/10.1063/1.5055513

[17] Mohammad Hosseini, H., Abdul Awal, A. S. M., \& Sam, A. R. M. (2016). Mechanical and thermal properties of prepacked aggregate concrete incorporating palm oil fuel ash. Sadhana, 41(10), 1235-1244. https://doi.org/10.1007/s12046-016-0549-9
[18] Norgaard, J. \& Othuman Mydin, M. A. (2013). Drywall thermal properties exposed to high temperatures and fire condition. Jurnal Teknologi, 62(1), 63-68. https://doi.org/10.11113/it.v62.1369

[19] BS EN 12:1996 (1996). Specification for Portland cement. British Standards Institution, London. https://doi.org/10.3403/00193324

[20] BS EN 882:1992 (1992). Specification for aggregates from natural sources for concrete. British Standard Institution, London

[21] BS EN 12390-3:2009 (2009). Testing Hardened Concrete. Compressive Strength of Test Specimens. British Standard Institution, London.

[22] ASTM C348-20:2020 (2020). Standard Test Method for Flexural Strength of Hydraulic-Cement Mortars. ASTM International, West Conshohocken, PA. https://doi.org/10.1520/C0348-21

[23] ASTM C496 / C496M-17: 2017 (2017). Standard Test Method for Splitting Tensile Strength of Cylindrical Concrete Specimens. ASTM International, West Conshohocken, PA. https://doi.org/10.1520/C0496_C0496M-17

[24] Muthusamy, K. \& Zamri, N. A (2016). Mechanical Properties of Oil Palm Shell Lightweight Aggregate Concrete Containing Palm Oil Fuel Ash as Partial Cement Replacement. KSCE Journal of Civil Engineering, 20(4), 1473-1481. https://doi.org/10.1007/s12205-015-1104-7

[25] Fu, Y., Wang, X., Wang, L., \& Li, Y. (2020). Foam Concrete: A State-of-the-Art and State-of-the-art Practice Review. Advances in Materials Science and Engineering, 6153602, 1-25. https://doi.org/10.1155/2020/6153602

[26] Othuman Mydin, M. A., Noordin, N. M., Utaberta, N., Mohd Yunos, M. Y., \& Segeranazan, S. (2016). Physical properties of foamed concrete incorporating coconut fibre. Jurnal Teknologi, 78(5), 99-105. https://doi.org/10.11113/jt.v78.8250

[27] Serri, E., Othuman Mydin, M. A., \& Suleiman, M. Z. (2014). Thermal properties of Oil Palm Shell lightweight concrete with different mix designs. Jurnal Teknologi, 70(1), 155159. https://doi.org/10.11113/jt.v70.2507

[28] Elrahman, M. A, El Madawy, M. E., Chung, S. Y., Sikora, P., \& Stephan, D. (2019). Preparation and characterization of ultra-lightweight foamed concrete incorporating lightweight aggregates. Applied Sciences, 9(7), 1-12. https://doi.org/10.3390/app9071447

[29] Hedjazi S. (2019). Compressive Strength of Lightweight Concrete. In Intech Open, 1-18. https://doi.org/10.5772/intechopen.88057

\section{Contact information:}

Md Azree OTHUMAN MYDIN, Senior Lecturer, PhD. Civil Engineering

(Corresponding author)

School of Housing, Building and Planning,

Universiti Sains Malaysia, 11800, Penang, Malaysia

E-mail: azree@usm.my

Mohd Nasrun MOHD NAWI, Senior Lecturer, PhD

Disaster Management Institute (DMI),

School of Technology Management and Logistics,

Universiti Utara Malaysia,

06010 Sintok, Kedah, Malaysia

E-mail: nasrun@uum.edu.my

Anas A. SALAMEH, Senior Lecturer, PhD

Department of Management Information Systems,

College of Business Administration,

Prince Sattam Bin Abdulaziz University,

165 Al-Kharj 11942, Saudi Arabia

Email: a.salameh@psau.edu.sa 